\title{
Serum sialic acid levels in health and disease
}

\author{
ANN CARTER AND N. H. MARTIN \\ From the Department of Chemical Pathology, St. George's Hospital Medical School, London
}

SYNOPSIS Sialic acid levels in normal and pathological sera estimated by the improved Svennerholm technique are reported. The increased levels demonstrable in rheumatoid arthritis, cirrhosis, $\gamma$ myelomata, and macroglobulinaemia are demonstrated as being explicable on the basis of increased production of proteins of normal sialic content.

Tentative reasons are given for the possibility that abnormal binding of sialic acid may occur in nephrotic sera and sera from $\beta$ globulin myelomata. The latter may be confused with 'macroglobulinaemia'.

The important part that neuraminic acid derivatives play in determining the specificity of virus haemagglutinins-their wide distribution through nature, their observed concentration in certain serum proteins, and the observed increase in these proteins in certain disease processes such as rheumatoid arthritis, myeloma, and macroglobulinaemia-have stimulated world-wide interest in the significance of the fluctuations of serum sialic acid levels in health and disease.

In 1936 Blix isolated 'sialic acid' from the mucin obtained from bovine submaxillary glands. Five years later Klenk (1941) isolated a similar compound from the grey matter of the central nervous system.

Although Blix (1938) assumed the presence of 'sialic acid' in certain of the serum proteins, it was not until 1955 that Böhm and Baumeister, by preparing a crystalline derivative from human serum, established the existence of sialic acid as a component of one of the prosthetic groups of the serum proteins.

The intensive study of the sialic acids and closely allied substances isolated from a variety of animal tissues indicated that these in fact formed a family of compounds with a common structure which may be considered to be the product of a condensation of $\mathrm{N}$ acetylhexosamine and pyruvic acid. To avoid confusion Blix, Gottschalk, and Klenk (1957) have suggested that the primary non-acetylated compound should be called neuraminic acid and 'sialic acid' should be used as a collective term for acetyl and glycocyl derivatives of neuraminic acid.

It is generally considered (Gottschalk, 1960) that human serum contains no free sialic acid and that

Received for publication 13 July 1961.

6
$90 \%$ of the serum sialic acid is bound to the $\alpha$ and $\beta$ globulins. Moreover, the only member of the 'sialic' family so far identified in human serum is the $\mathbf{N}$ acetyl derivative of neuraminic acid.

The data which have accumulated in the last five years on the variations in concentration of sialic acid in both normal and pathological human sera are scattered through the international literature, and are based on analytical methods of questionable specificity. Moreover, it has been common practice to report levels in terms of $\mathrm{mg}$. $/ 100 \mathrm{ml}$. serum. If, as is almost certainly true, the sialic acid circulating is bound and not free, and if, as Gottschalk suggests, the major portion is bound to protein, it would be more logical to return serum sialic acid levels as $\mathrm{mg} . / 100 \mathrm{mg}$. serum proteins or, if we assume that albumin carries a negligible amount of sialic acid, as mg./100 mg. globulin.

\section{METHODS AND MATERIALS}

Until 1957 three reagents were used most commonly for the development of the colour complexes by which quantitative estimates were made of the sialic acid content of biological fluids. These were Bial's orcinol reagent used in the method developed by Klenk and Langerbeins (1941), and the direct Ehrlich reaction and the diphenylamine reagent of Dische used by Werner and Odin (1952). It has always been recognized that none of these reagents was entirely satisfactory either by virtue of specificity or sensitivity. In 1957 Svennerholm, in a careful appraisal of the orcinol technique, demonstrated that the replacement of orcinol by resorcinol enhanced the sensitivity of the reaction by $50 \%$ and that by careful selection of the wavelength at which the measurements were made, specificity could also be enhanced. By detailed attention to techniques of chromatographic separation 
(1958) he still further increased the specificity of his method.

In 1959 Warren introduced an alternative technique for the quantitative estimation of sialic acid using thiobarbiturate.

Both Warren's and Svennerholm's techniques appear to be advances over the older methods. The analyses in this paper were carried out in strict accordance with the method described by Svennerholm $(1957,1958)$ using a standard containing $18 \% \mathrm{~N}$ acetyl neuraminic acid.

Protein concentration was determined by the microKjeldahl technique using $\mathbf{6 . 2 5}$ as the factor.

Ultracentrifugal analyses were carried out on dialyzed samples diluted to a $1 \% \mathrm{w} / \mathrm{v}$ protein concentration in phosphate buffer, $p \mathrm{H} 8, I=0.2$ in $0.15 \mathrm{M} \mathrm{NaCl}$ in the Svedberg oil-driven centrifuge.

\section{SAMPLING}

Blood was drawn from the antecubital vein of selected patients, placed in clean sterile bottles, and left to clot. The specimen was centrifuged and the serum reserved for analysis.

\section{RESULTS}

The data presented in this paper are based on analyses carried out on limited groups of patients in whom there was unequivocal clinical and/or histopathological evidence of the nature of the disease. The results are presented in tabular form.

The investigations sprang primarily from our special interest in patients whose sera contained excess of the 19S component. It is recognized (Martin, 1960) that these cover a diversity of conditions but because other authors have made a heading 'macroglobulinaemia' we have done likewise in Table I. Table I gives serum levels in normals and in the groups of diseases studied. Values are shown first as $\mathrm{mg} . / 100 \mathrm{ml}$. serum for comparison with existing data, secondly, in $\mathrm{mg} . / 100 \mathrm{mg}$. total protein, and finally, values have been worked out as $\mathrm{mg} . / 100 \mathrm{mg}$. of total circulating globulin. Though we have calculated the relationship to further subdivisions of $\alpha, \beta$, and $\gamma$ globulins, the variance from the

TABLE I

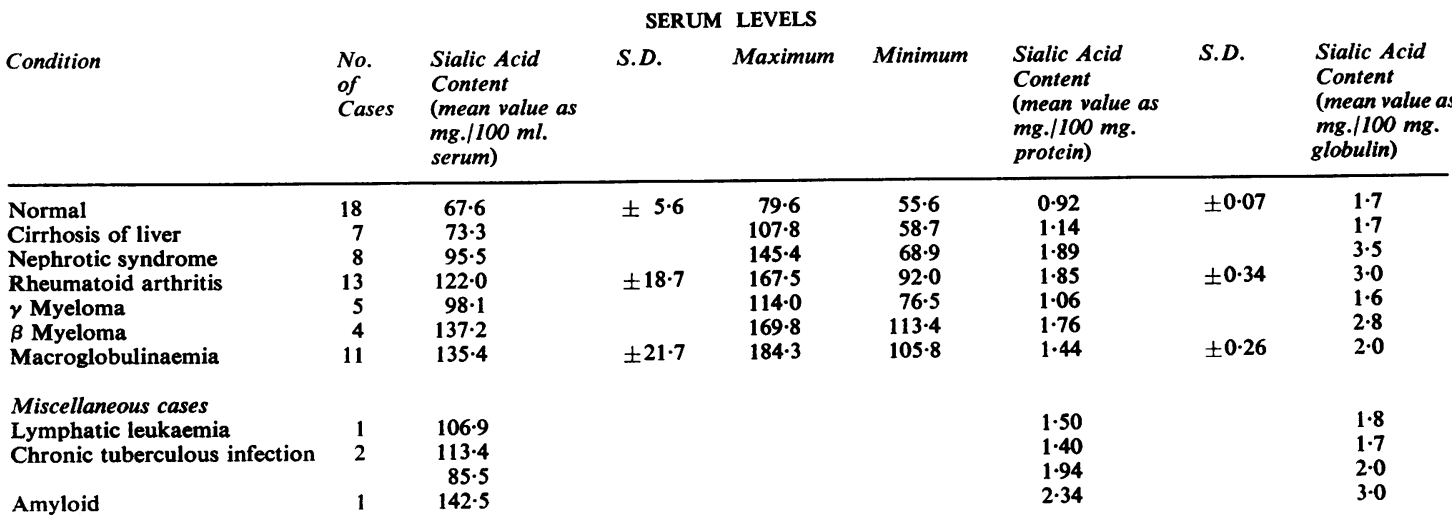

TABLE II

ANALYSIS OF ISOLATED PROTEINS ACCORDING TO MOBILITY

\begin{tabular}{|c|c|c|c|c|}
\hline & Source & Method of Separation & $\begin{array}{l}\text { Approximate } \\
S_{\mathrm{y} 0} \text { at } 1 \%\end{array}$ & $\begin{array}{l}\text { Sialic Acid } \\
\text { (mg./100 mg.) }\end{array}$ \\
\hline$\gamma$ globulin & $\begin{array}{l}\text { Normal pool EG. } 105 \\
\text { Normal pool EG. } 137 \\
\text { Myeloma No. } 34 \\
\text { Myeloma No. } 116\end{array}$ & $\begin{array}{l}\text { Ether fractionation } \\
\text { Ether fractionation } \\
\text { Ether fractionation } \\
\text { Salt fractionation }\end{array}$ & $\begin{array}{l}7 \\
7 \\
7 \\
7\end{array}$ & $\begin{array}{l}0.23 \\
0.23 \\
0.22 \\
0.75\end{array}$ \\
\hline$\beta$ globulin & $\begin{array}{l}\text { Myeloma No. } 12 \\
\text { Myeloma No. } 73\end{array}$ & $\begin{array}{l}\text { Ether fractionation } \\
\text { Ether fractionation }\end{array}$ & $8 \cdot 5$ & $\begin{array}{l}0 \cdot 89 \\
1 \cdot 01\end{array}$ \\
\hline $19 S$ fraction & $\begin{array}{l}\text { Macro No. } 8 \\
\text { Macro No. } 7 \\
\text { Macro No. } 17 \\
\text { Macro No. } 27 \\
\text { Macro No. } 30 \\
\text { Macro No. } 28 \\
\text { Macro No. } 18 \\
\text { Macro No. } 4\end{array}$ & $\begin{array}{l}\text { Water dilution } \\
\text { Water dilution } \\
\text { Water dilution } \\
\text { Water dilution } \\
\text { Water dilution } \\
\text { Water dilution } \\
\text { Water dilution } \\
\text { Water dilution }\end{array}$ & $\begin{array}{l}19 \\
19 \\
19 \\
19 \\
19 \\
19 \\
19 \\
19\end{array}$ & $\begin{array}{l}1 \cdot 12 \\
1 \cdot 13 \\
1 \cdot 30 \\
1 \cdot 43 \\
1 \cdot 46 \\
1 \cdot 14 \\
1 \cdot 29 \\
1 \cdot 42\end{array}$ \\
\hline$\beta$ globulin transferrin & Normal pool plasm & Cellulose column & $5 \cdot 3$ & 1.44 \\
\hline
\end{tabular}


TABLE III

ANALYSIS OF SERA GROUPED ACCORDING TO PRESENCE OF ABNORMAL CONSTITUENTS DEMONSTRABLE BY ULTRACENTRIFUGAL ANALYSIS

\begin{tabular}{|c|c|c|c|c|c|}
\hline & No. of Patients & $\begin{array}{l}\text { Mean Value of } \\
\text { Sialic Acid } \\
(\mathrm{mg} .100 \mathrm{ml} . \text { serum })\end{array}$ & Maximum & Minimum & $\begin{array}{l}\text { Mean Value of } \\
\text { Sialic Acid } \\
\text { (mg./100 mg. serum) }\end{array}$ \\
\hline $\begin{array}{l}\text { Gross excess of } 7 \mathrm{~S} \\
{ }^{1} \text { Excess of S8-S14 } \\
{ }^{1} \text { Excess of } 19 \mathrm{~S}\end{array}$ & $\begin{array}{r}5 \\
5 \\
11\end{array}$ & $\begin{array}{r}98 \cdot 1 \\
131 \cdot 5 \\
137 \cdot 2\end{array}$ & $\begin{array}{l}114 \\
169 \cdot 8 \\
184 \cdot 3\end{array}$ & $\begin{array}{r}76 \cdot 5 \\
107 \cdot 3 \\
105 \cdot 8\end{array}$ & $\begin{array}{l}1.06 \\
1.96 \\
1.44\end{array}$ \\
\hline
\end{tabular}

${ }^{1}$ More than $10 \%$ by ultracentrifugal analysis

calculation for total globulins did not seem to justify their inclusion.

Table II shows estimation of the sialic content of globulins isolated and identified from various sera.

Table III is an arbitrary arrangement to show the apparent relationship of sialic acid content to size as judged by sedimentation data. This table shows clearly that while increases in serum sialic levels are associated with the presence of excess of the $19 \mathrm{~S}$ globulins, they may be even more striking in the presence of globulins of intermediate sedimentation value most often associated with the so called $\beta$ globulin myelomata.

\section{DISCUSSION}

If as Gottschalk points out, $90 \%$ of sialic acid in normal sera is bound to the $\alpha$ and $\beta$ globulins it is reasonable to anticipate that conditions in which these fractions of the serum protein pattern are increased may also show a raised level of sialic acid. Thus any marked change in the $\alpha$ and $\beta$ serum protein fractions may be reflected in a high sialic acid/globulin ratio, whereas an increase in the $\alpha$ fraction would have little effect on this ratio.

All the patients suffering from rheumatoid arthritis in this series showed a significant increase in $a$ globulins. These are the globulins which in normal sera are richest in sialic acid (Winzler, 1958). We have no values for purified $\alpha_{2}$ macroglobulin to compare with the values quoted by Müller-Eberhard, Kunkel, and Franklin (1956) of 2.30, and Schulze's $1.8 \mathrm{mg}$./100 mg. (quoted by Winzler, 1958). However, allowing for margins of error for such calculations, the values shown in this series for the ratio of sialic acid to globulins in rheumatoid arthritis would be entirely in keeping with the high values given in the literature for these isolated $a_{2}$ globulins.

Two patients suffering from rheumatoid arthritis in this series had demonstrable amyloid deposition; the sialic levels in these two were 1.48 and $2.18 \mathrm{mg}$./ $100 \mathrm{mg}$. protein respectively.

The electrophoretic analyses of the sera from nephrotics are characteristically rich in $\alpha$ and $\beta$ globulins. They differ from the sera of patients suffering from rheumatoid arthritis in having a significant increase in the low-density lipoproteins known to be associated with these fractions. Yamakawa and Suzuki (1951) and Klenk and Lauenstein (1953) extracted glycolipids from the stroma of horse red cells, and demonstrated that these water-soluble substances may contain as much as $24 \%$ of substituted neuraminic acid. If, as seems possible, analogous compounds are elaborated in the human red cell stroma, such glycolipids could contribute to the increase in low-density, watersoluble lipids known to occur in nephrotics and play a part in producing the high serum sialic acid levels observed in these cases.

The sialic acid levels in the limited series of cirrhotics studied are above the normal limits but when they are adjusted for the relative increase in globulin it is clear that the apparent excess of sialic acid is explicable in terms of gross globulin overproduction, which is well known to occur in a percentage of cirrhotics (Martin and Davies, 1955).

None of the patients suffering from myelomatosis had demonstrable amyloid or para-amyloid deposits; nor had the patients recorded here as suffering from macroglobulinaemia, though para-amyloid material is known to be deposited on cccasion in both these conditions. Two of the levels recorded from the patients with $\gamma$ globulin myelomatosis are explicable on the basis of an abnormal production of a normal globulin.

The sera from myelomata in which $\beta$ globulins predominate give high sialic levels. While this could be explained on the same basis as the levels in cirrhosis and the $\gamma$ myelomata, it is in this group that globulins of unusual sedimentation rate are found (Martin, 1961). One cannot therefore exclude the possibility that in these patients abnormal globulins may be being produced with an unusually high sialic acid/protein ratio. If this were so one would expect such proteins to have somewhat higher mobilities than related proteins with a lower sialic acid content.

Two conditions of which we have made no detailed 
study are reported as having high circulating sialic acid levels. They are advanced neoplastic disease and active tuberculosis. In 15 patients suffering from advanced carcinoma, Winzler (1958) reports a mean level of $142 \mathrm{mg} . / 100 \mathrm{ml}$. with a standard deviation of $13 \cdot 1$, while in 16 patients with tuberculosis the same author records a mean value of $178 \mathrm{mg} . / 100$ $\mathrm{ml}$. with a standard deviation of $12 \cdot 6$, compared with a mean level of sialic acid for normal sera of $60.0 \pm 3.7 \mathrm{mg} . / 100 \mathrm{ml}$.

Müller-Eberhard et al. (1956) have given values for the sialic acid in ' $\beta_{2} 19 \mathrm{~S}$ ' globulin isolated from normal patients and from a patient with macroglobulinaemia. Our figures for pathological sera fractions are somewhat lower than theirs (see Table II) but the essential point which they made, that these globulins of high molecular weight are relatively rich in sialic acid, is amply confirmed.

The data on the isolated 19S component suggests that there is no substantial difference between the sialic acid content of these globulins in health and disease.

So far as deductions can be made from the accumulated data it would appear that observed increases in serum sialic acid levels are usually associated with an increase in circulating serum proteins normally rich in sialic acid. Two classes may be exceptions to this statement, namely, those nephrotics in whose sera high sialic acid levels are found and the $\beta$ myelomata. It is the latter that may cause confusion if the level of circulating sialic acid is used among the diagnostic criteria for the presence of the $19 \mathrm{~S}$ or $\beta_{2} \mathrm{M}$ component.

We wish to acknowledge the financial support from the research funds of St. George's Hospital and from The 음 British Empire Cancer Campaign during the progress of $\frac{\mathrm{m}}{\mathrm{a}}$ this work.

We wish also to acknowledge the facilities afforded us $\varrho$ in the Biophysics Department of The Lister Institute of and the gift of the sialic acid standard by Professor $\vec{\circ}$ Walter Morgan of that Institute.

\section{REFERENCES}

Blix, G. (1936). Hoppl-Seylers Z. physiol. Chem., 240, 43. (1938). Skand. Arch. Physiol., 80, 46. Gottschalk, A., and Klenk, E. (1957). Nature (Lond.), 179, 1088.

Böhm, P. (1958). Quoted by Gottschalk, A. (1960), p. 91.

-, and Baumeister, L. (1955). Klin. Wschr., 33, 712.

Gottschalk, A. (1960). The Chemistry and Biology of Sialic Acids and Related Substances. University Press, Cambridge.

Klenk, E. (1941). Hoppl-Seylers Z. physiol. Chem., 268, 50.

-, and Langerbeins, H. (1941). Ibid., 270, 185.

, and Lauenstein, K. (1953). Ibid., 295, 164.

Martin, N. H. (1960). Quart. J. Med., n.s., 29, 179. (1961). Lancet, 1, 237.

, and Davies H. (1955). Ibid., 2, 1011.

Müller-Eberhard, H. J., Kunkel, H. G., and Franklin, E. C. (1956). Proc. Soc. exp. Biol. (N.Y.), 93, 146.

Svennerholm, L. (1957). Biochim. Biophys. Acta, 24, 604.

- (1958). Acta chem. scand., 12, 547.

Warren, L. (1959). J. biol. Chem., 234, 1971.

Werner, I., and Odin, L. (1952). Acta Soc. Med. upsalien, 57, 230.

Winzler, R. J. (1958). In Ciba Foundation Symposium on the Chemistry and Biology of Mucopolysaccharides, p. 245. Churchill, London.

Yamakawa, T., and Suzuki, S. (1951). J. Biochem (Tokyo), 38, 199.$$
\text { 은 }
$$ 